Boletín de la Sociedad Geológica Mexicana

VOLUMEN 65, NÚM. 2, 2013, P. 235-248

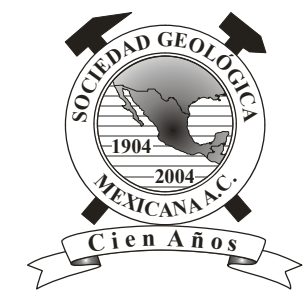

\title{
An exceptionally preserved upogebiid (Decapoda: Reptantia) from the Eocene of California
}

\author{
Carolin Haug ${ }^{1, *}$, Torrey Nyborg ${ }^{2}$, Francisco J. Vega ${ }^{3}$ \\ ${ }^{1}$ Department of Cytology and Evolutionary Biology, Zoological Institute and Museum, University of Greifswald, Soldmannstrasse 23, \\ 17487 Greifswald, Germany. \\ ${ }^{2}$ Department of Earth and Biological Sciences, Loma Linda University, Loma Linda California, 92350, United States of America. \\ ${ }^{3}$ Instituto de Geología, Universidad Nacional Autónoma de México, Ciudad Universitaria, Coyoacán, 04510 México, D.F., México. \\ *carolin.haug@palaeo-evo-devo.info
}

\begin{abstract}
Construction excavation within member "B" of the middle Eocene-aged Santiago Formation at Bressi Ranch in the southern part of the City of Carlsbad, California, USA, have produced exceptionally preserved upogebiid fossils. While most fossil upogebiids are only known fragmentarily, the specimens described here are preserved as relatively complete articulated specimens. Preserved structures include: the cephalothoracic shield with a short rostrum, a well-developed cervical groove and anterior coarse tuberculation; the pleon, with a characteristic trapezoidal first tergite and the second tergite representing the largest of the series; the appendages including (fragmentary) maxillipeds two and three, and the five walking limbs; the tail fan with uropods with both sub-triangular rami possessing bulging anterior edges and one (endopod) or two (exopod) keels running in parallel to the anterior bulging edge, the exopod lacking a diaresis, and the telson being sub-rectangular with a median suture. Exceptional minute details preserved are the bases of setae on the uropods and muscles in pleomere six. These muscles show fiber bundles about $80 \mu \mathrm{m}$ in diameter, and individual fibers about $10 \mu \mathrm{m}$ in diameter. The specimens were documented with up-to-date imaging techniques, including stereo photography or depth-map-based surface reconstructions. Due to the exceptional preservation, the fossils can be recognized as an upogebiid of the species Upogebia aronae sp. nov. As numerous specimens have been found at that locality, this discovery indicates similarly dense populations as seen in modern fauna.
\end{abstract}

Keywords: Upogebiidae, fossilized muscles, paleo-population, calcium phosphate, 3D-imaging.

\section{Resumen}

La excavación durante una construcción en el miembro "B” de la Formación Santiago de edad Eoceno medio en el Rancho Bressi, ubicado en la porción sur de la Ciudad de Carlsbad, California, USA, ha producido fósiles de upogébidos excepcionalmente bien preservados. Aunque la mayoría de upogébidos fósiles se conocen de restos fragmentarios, los aqui descritos están preservados como especímenes articulados, relativamente completos. Las estructuras preservadas incluyen: el escudo cefalotorácico con un rostro corto, un surco cervical bien desarrollado y gruesos tubérculos en la porción anterior; pleón con un primer terguito característicamente trapezoidal y el segundo terguito representa el más grande de la serie; los apéndices incluyen los maxilipedos dos y tres (fragmentarios) y las cinco patas ambulacrales; el abanico caudal con urópodos con ambos rami subtriangulares, que poseen márgenes anteriores prominentes y una (en endópodo) o dos (en exópodo) quillas que corren paralelo al margen prominente, el exópodo carece de diéresis y el telson es subrectangular con un sutura media. Detalles diminutos excepcionales son las bases de las setas en los urópodos y los músculos en el pleómero seis. Estos músculos muestran paquetes fibrosos de aproximadamente 80 pm de diámetro, y fibras individuales de aproximadamente $10 \mu \mathrm{m}$ de diámetro. Los ejemplares se documentarons con técnicas de imagenología de punta, incluyendo estereofotografía y reconstrucciones de superficie basadas en profundidad de mapeo. Debido a la excepcional preservación, los 
fósiles pueden ser reconocidos como un upogoébido de la especie Upogebia aronae sp. nov. Dado que se han encontrado numerosos especimenes en esta localidad, este hallazgo indica poblaciones similarmente densas como las observadas en la fauna moderna.

Palabras Clave: Upogebiidae, músculos fosilizados, paleopoblación, fosfato de calcio, imágenes $3 D$.

\section{Introduction}

Upogebiids are decapod crustaceans, part of Reptantia, the group of primarily ground-living forms including lobsters, crayfish and crabs. They are mostly active burrowers, which is of ecological importance, as they heavily influence their direct environment (Dworschak et al., 2012 and references therein). The fossil record of upogebiids reaches possibly back to the Jurassic (e.g., Glaessner, 1969; Schram, 1986; Fraaije et al., 2006). Upogebiids are relatively rare fossil elements (Fraaije et al., 2006), although they should be relatively easily preserved in the fossil record due to their burrowing life style and high chances to become directly buried after death. Therefore, fossil findings of several specimens in the same place are important for paleoecological and paleobiogeographical approaches.

Fossil upogebiids are usually not preserved as complete specimens (e.g., Bishop and Williams, 2005; Fraaije et al., 2006), but even for better preserved specimens, species descriptions usually focus on characters that are thought to be of diagnostic value; other characters are in most cases neither mentioned nor documented. This is specially the case in descriptions of extant upogebiids, which hampers comparisons between extant and fossil species. Exceptionally preserved fossil upogebiids are therefore important for bridging the gaps in the knowledge on the morphologies of extant and fossil upogebiids and for developing a more comprehensive approach including both fossil and extant forms.

We present here exceptionally preserved specimens of a new upogebiid species from the Eocene of California, USA. Due to the highly detailed preservation, the morphology of the new species is described with all observable details with up-to-date imaging techniques.

\section{Material and methods}

\subsection{Material}

The specimens were collected from sedimentary rocks exposed from mass grading operations at Bressi Ranch in the southern part of the City of Carlsbad, California, USA (Figure 1). Construction operations exposed approximately a $110 \mathrm{~m}$ thick sequence of estuarine to nearshore marine and non-marine sandstone, siltstone, mudstone, and cobble breccia beds of member "B" of the Eocene-age Santiago

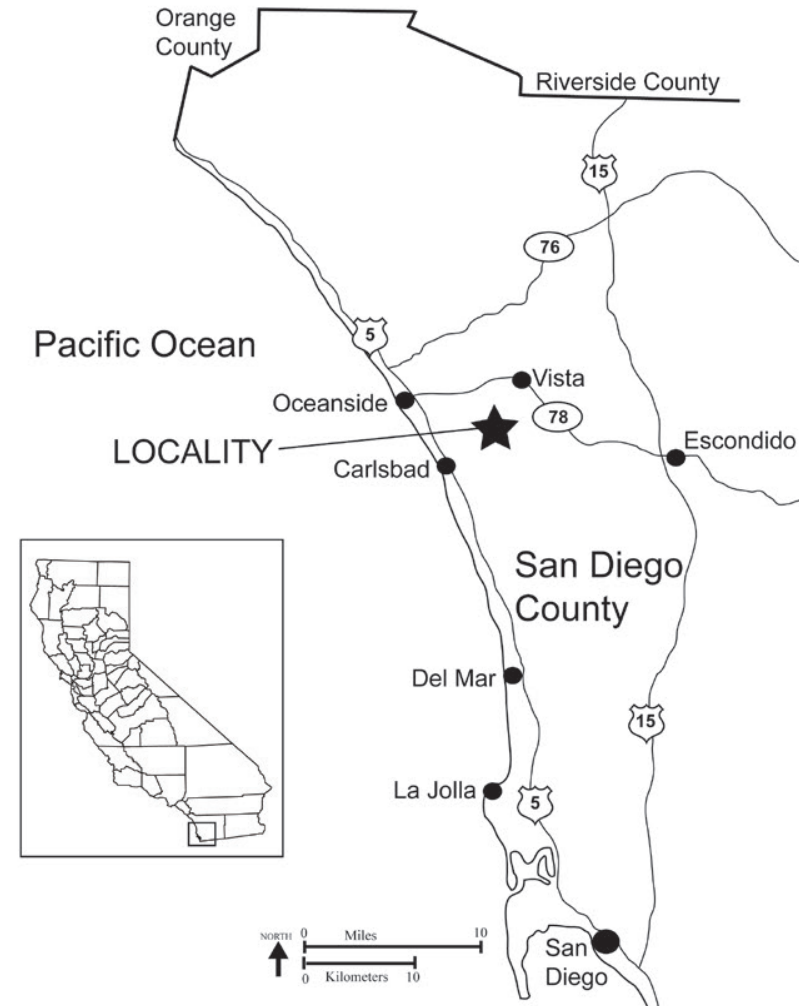

Figure 1. Location of the Bressi Ranch project site in northwestern San Diego County, California.

Formation (Tan and Kennedy, 1996; Deméré and Murphy, 2006). A detailed paleontological mitigation report was prepared discussing the fossil-bearing localities at this site (Deméré and Murphy, 2006). The Bressi Ranch project site is located approximately three miles east of Interstate 5 in the southern part of the City of Carlsbad, California (Deméré and Murphy, 2006). The site is bounded by El Camino Real to the west and Palomar Airport Road to the north. Melrose Drive and Poinsettia Lane are located just to the east of the eastern boundary of the project site (Deméré and Murphy, 2006). Elevations of grading activities at Bressi Ranch spanned approximately $108 \mathrm{~m}$, from $30.5 \mathrm{~m}$ above sea level in the western portion of the project site to 138.7 $\mathrm{m}$ in the northeastern portion (Deméré and Murphy, 2006).

Woodring and Popenoe (1945) named the Santiago Formation for a sequence of Eocene fossiliferous marine siltstone and sandstone beds that crop out in the Santa Ana Mountains in Orange County, California. Wilson (1972) later extended the Santiago Formation to include a sequence of Eocene marine and nonmarine strata in the Oceanside 
and Carlsbad areas in northwestern San Diego County. Wilson (1972) also subdivided the Santiago Formation into three informal members: a basal marine member (member A); a middle marine member (member B); and an upper nonmarine member (member $\mathrm{C}$ ). Member "B" of the Santiago Formation has produced well-preserved fossils from many localities in Carlsbad and elsewhere in northern San Diego County (Deméré and Walsh, 1993). Fossil decapods have been previously reported from the basal strata of member B (Schweitzer and Feldmann, 2002) but did not include the upogebiid fossils described here.

Twenty three fossil localities were discovered at the Bressi Ranch project site (SDSNH Locality 5548 through 5570; Deméré and Murphy, 2006). Recovered fossils consisted in fossil plants, poriferans (sponges), bryozoans, mollusks (gastropods and bivalves), arthropods (crabs, shrimp, and barnacles), vertebrates (fishes, amphibian, turtles, crocodilians, and mammals), and ichnofossils (burrows and a coprolite) (Deméré and Murphy, 2006).

The upogebiid fossil specimens described here were collected from SDSNH locality 5567, which was discovered on Lot 15 southwest of the intersection of El Fuerte Street and Gateway Road at an approximate elevation of 415 feet (Deméré and Murphy, 2006). Fossils were collected from an approximately $1.5 \mathrm{~m}$ thick greenish-gray claystone containing laminated interbeds of siltstone and very finegrained sandstone. Fossils at this locality were collected by hand quarrying and consist of whole and well-preserved upogebiid fossils described here and well preserved shells of estuarine mollusks (Deméré and Murphy, 2006).

A fossil mandible of the small brontothere, Metarhinus sp., was discovered at an elevation of approximately 124.4 $\mathrm{m}$ on the Bressi Ranch project site, and is indicative of an early Uintan North American Land Mammal Age (NALMA) correlation (Walsh, 1996). Sedimentary deposits of member "B" of the Santiago Formation exposed on other project sites in the vicinity of the Bressi Ranch project area have yielded numerous specimens of fossil land mammals that are characteristic of the early part of the Uintan NALMA (Walsh, 1996), placing a middle Eocene (approximately $48 \mathrm{Ma}$ to $45 \mathrm{Ma}$ ) time period for the Bressi Ranch project site (see Deméré and Murphy, 2006 for further discussion).

Specimens described here and additional specimens are housed at the San Diego Natural History Museum. The twelve best preserved specimens form the basis for the presented description.

\subsection{Documentation}

All specimens were photographed under evenly distributed polarized light with a Canon Rebel T3i and an EF-S $18-55 \mathrm{~mm}$ lens or a MP-E $65 \mathrm{~mm}$ lens. The light was provided by a Canon Macro Twin Lite MT-24EX flashlight equipped with polarization filters; a second crossed polarizer was placed in front of the lens. The polarized light significantly enhanced the color contrast between the matrix and the fossil (see Schaarschmidt, 1973; Bengtson, 2000; Kerp and Bomfleur, 2011; Haug et al., 2011). To optimize the sharpness of the images, several images (frames) were documented in differing focal planes and fused with the freely available software CombineZM/CombineZP (image fusion). To enlarge the field of view, several adjacent areas of the specimen were documented and stitched with the freely available software Microsoft Image Composite Editor (ICE) or with Adobe Photoshop CS3 (image stitching). Often both methods were combined (composite imaging; Haug et al., 2008; Kerp and Bomfleur, 2011). Further processing was done in Adobe Photoshop CS3 and GIMP. On all images the brightness and contrast as well as the color balance were optimized; additionally the filter 'mask unsharp' was applied. To enhance the color contrast further in some images, the green channel and the cyan channel were desaturated (Figure 2C, D).

The even lighting flattens out the relief, with this preventing artifacts caused by shadows. Yet, also the relief can provide significant information. Therefore, red-cyan stereo images were produced for specimens with sufficient relief based on images differing in viewing angle (Haug et al., 2009). Due to the color interference of the greenish matrix with the standard cyan channel, images were transformed into gray scale before the stereo images were arranged.

Some specimens were additionally documented under macro-fluorescence settings (e.g. Figure 3C; Haug and Haug, 2011; Haug et al., 2011). For that purpose, the camera was equipped with a red filter; cyan filters were placed in front of four fiber-light sources that provided even lighting. While the matrix remained dark, the animals showed autofluorescence under these settings.

Details such as the maxillipeds or the chelae were documented using the MP-E $65 \mathrm{~mm}$ macro lens and an aperture of 2.8. Stacks were recorded with $20 \mu \mathrm{m}$ distance between the frames in z-axis. These stacks were then processed in Image Analyzer: Based on the unsharpness a virtual surface was calculated; a fused sharp image of the stack was rendered onto this surface. From this texture surface a red-blue stereo image was recorded (e.g. Figure 4I, J).

Small details such as setal bases and muscles were documented with a ScopeTek DCM 510 ocular camera on a Leica DM 2500P with $2.5 \mathrm{x}, 4 \mathrm{x}$ and $10 \mathrm{x}$ objectives resulting in about $25 \mathrm{x}, 40 \mathrm{x}$ and $100 \mathrm{x}$ magnification. Stacks were recorded with $50 \mu \mathrm{m}, 20 \mu \mathrm{m}$ and $5 \mu \mathrm{m}$ distance in $\mathrm{z}$-axis (depending on the magnification). The stacks were processed with Image Analyzer as explained above.

For morphological comparison, a female specimen of the extant upogebiid species Upogebia pugettensis, Dana, 1852 (determined after Williams, 1986) was documented in liquid under polarized light and with stereo images, using the same equipment and settings as for the fossil specimens. The specimen is housed in the invertebrate zoological collection of the Yale Peabody Museum of Natural History, New 
Haven, under the repository number YPM IZ 058041; it was removed from a larger sample stored under YPM IZ 041076.

The morphological description of the new fossil species was prepared following the descriptive matrix approach (see Supplement; Haug et al., 2012). The description is additionally given here as plain text, which was extracted from the descriptive matrix.

\section{Systematic Paleontology}

\author{
Malacostraca Latreille, 1802 \\ Decapoda Latreille, 1802 \\ Pleocyemata Burkenroad, 1963 \\ Reptantia Boas, 1880 \\ Gebiidea de Saint Laurent, 1979 \\ Upogebiidae Borradaile, 1903 \\ Upogebia Leach, 1814
}

Type species: Cancer (Astacus) stellatus Montagu, 1808 by monotypy.

\section{Upogebia aronae sp. nov.}

\subsection{Etymology}

In honour of Geraldine Aron, a previous employee of the San Diego Natural History Museum, who collected the specimens.

\subsection{Holotype and additional material}

Specimens described here were collected at the Bressi Ranch project site and are housed at the San Diego Natural History Museum under SDSNH locality 5567. Twelve specimens were used to describe the new taxa reported here consisting of holotype SDSNH 104562 and paratypes 104558-104561, 104564-104566, 104568, 104577, and 104580-104581.

\subsection{Locus typicus}

SDNHM locality 5567 at the Bressi Ranch project site (Deméré and Murphy, 2006). Lithostratigraphic and biochronologic framework matches sedimentary deposits of member "B" of the Eocene-age Santiago Formation as described by Wilson (1972) and mapped by Deméré and Murphy (2006).

\subsection{Diagnosis}

Small, slender and unornamented rostrum. Surface of cephalothoracic shield anterior to cervical groove is coarsely ornamented with tubercles not arranged in any recognizable pattern. Uropod with more or less triangular rami. Anterior edges of both rami are bulged. Exopod with two keels running parallel to the bulging anterior edge; lacking diaresis. Endopod with one keel running parallel to the bulging anterior edge. Sub-rectangular telson, posterior edge shorter than the anterior; midline marked by a distinct suture. Convex posterior edge with a weak median notch.

\subsection{Description (extracted from descriptive matrix)}

Small decapod crustacean. Body organized in two main tagmata, cephalothorax and pleon, in total 20 segments (ocular segment plus 19 appendage-bearing segments) (Figures 2, 3A-C).

Cephalothorax dorsally forming shield (carapace), including ocular segment and 13 appendage-bearing segments. Length ratio cephalothorax vs. pleon about 0.6 (Figure 2D, E). Cephalothoracic shield (carapace) about 1.4 times as long as wide (in dorsal view) (Figure 2D, E). Anterior edge drawn out into short, relatively slender, triangular rostrum (Figure 3D, E). Rostrum appears to lack ornament (Figure 3D, E). Shield with pronounced, U-shaped groove (cervical groove); opening of the $\mathrm{U}$ facing anteriorly (Figure 3D, E). Surface of cephalothoracic shield anterior of the cervical groove ornamented with coarse tubercles not arranged in any recognizable pattern (Figure 3F). Shield surface posterior of the cervical groove appears to be smooth (Figure 2D).

Post-ocular segment 14 (pleomere 1) dorsally forming a separate tergite (Figures 2D, E, 3B). Tergite of pleomere 1 is trapezoidal in shape, posterior edge more than 1.5 times as long as anterior edge (Figure 2D, E). Length of tergite of pleomere 1 is slightly shorter than the width of anterior edge (Figure 2D, E).

Post-ocular segment 15 (pleomere 2) dorsally forming a separate tergite. Tergite of pleomere 2 rectangular in shape, slightly wider than tergite of pleomere 1 , significantly longer than tergite of pleomere 1 and 3 (about 1.4 times) (Figure $2 \mathrm{D}, \mathrm{E})$. Length to width ratio of tergite of pleomere 2 about 0.53 (Figure 2D, E).

Post-ocular segment 16 (pleomere 3 ) dorsally forming a separate tergite. Tergite of pleomere 3 rectangular in shape. Length to width ratio of tergite of pleomere 3 about 0.38 (Figure 2D, E).

Post-ocular segment 17 (pleomere 4) dorsally forming a separate tergite. Tergite of pleomere 4 rectangular in shape, slightly shorter than preceding tergite. Length to width ratio of tergite of pleomere 4 about 0.38 (Figure 2D, E).

Post-ocular segment 18 (pleomere 5) dorsally forming a separate tergite. Tergite of pleomere 5 rectangular in shape, slightly longer, but slightly narrower than preceding tergite. Length to width ratio of tergite of pleomere 5 about 0.45 (Figure 2D, E).

Post-ocular segment 19 (pleomere 6) dorsally forming a separate tergite. Tergite of pleomere 6 rectangular in shape, slightly shorter and narrower than preceding tergite. Length to width ratio of tergite of pleomere 6 about 0.45 (Figure 2D, E). 

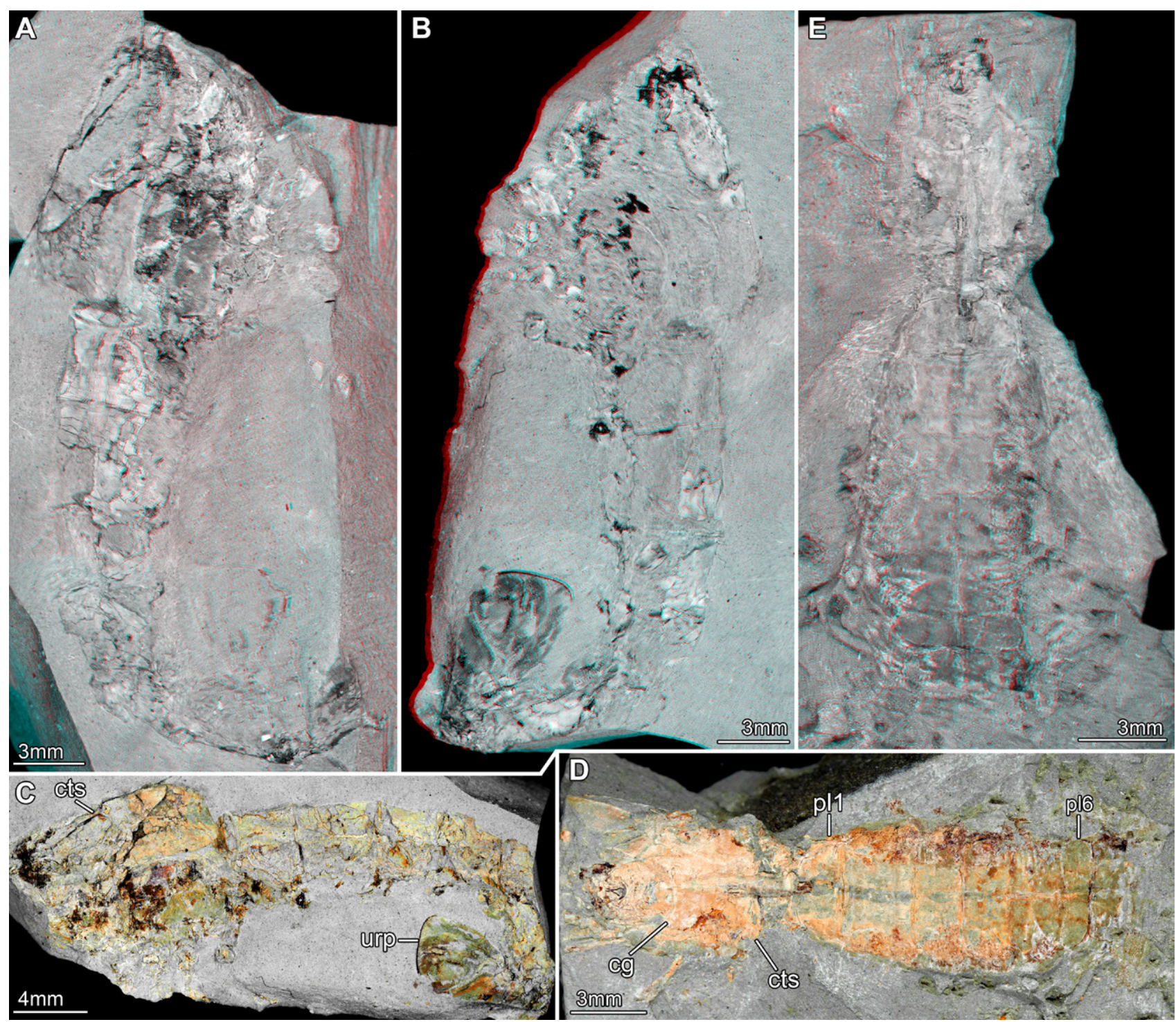

Figure 2. Overview images of Upogebia aronae sp. nov. A, B, and E red-cyan stereo images; C and D crossed-polarized light images with desaturated green and cyan channel to enhance contrast. A-C) SDNHM 104561; lateral aspect. A) Counterpart. B-C) Part with well-preserved uropods. D-E) SDSNH 104558; dorsal aspect. Abbreviations: $\mathrm{cg}=$ cervical groove; $\mathrm{cts}=$ cephalothoracic shield; $\mathrm{pl}=$ pleomere; $u$ urp $=$ uropod.

Eyes, antennulae, antennae, mouthparts and maxilliped 1 not preserved or not accessible. Appendage of post-ocular segment 7 (maxilliped 2) small compared to walking legs; elongate, slender, at least three articles preserved (Figures 3B, 4J). Maxillipeds 2 insert close to each other, point anteriorly. Articles of maxilliped 2 all about 2.5 times as long as wide. Second article smaller than first, but larger than third.

Appendage of post-ocular segment 8 (maxilliped 3) more robust and leg-like than maxilliped 2, diameter at least 3 times the diameter of maxilliped 2; at least two articles preserved (Figures 3C, 4J). Maxillipeds 3 inserted lateroposteriorly to maxillipeds 2 , pointing anteriorly. Proximal preserved article about as long as wide (diameter), but incomplete. Distal preserved article about 1.3 times as long as wide, but incomplete.
Appendage of post-ocular segment 9 (first "walking" leg, thoracopod 4) with five preserved articles (Figure 4A-G). First preserved article (ischium) short, almost triangular in lateral view. Second preserved article (merus) elongate, almost 5 times the length of the ischium; more than 3 times as long as wide. Third preserved article (carpus) shorter, about half the length of the merus; more than 2 times as long as wide. Fourth preserved article (propodus) slightly longer than carpus, about the same diameter; with a short elongate triangular spine-like protrusion (functional fixed finger) at the medio-distal edge (Figure 4H, I). Length of fixed finger about as long as the diameter of the main article. Fifth preserved article (dactylus) forms a functional movable finger; elongate, triangular, slightly inwards-curved, about as long as the width of the merus (Figure 4H, I). Joint formed by merus and carpus allows folding back the distal part of 

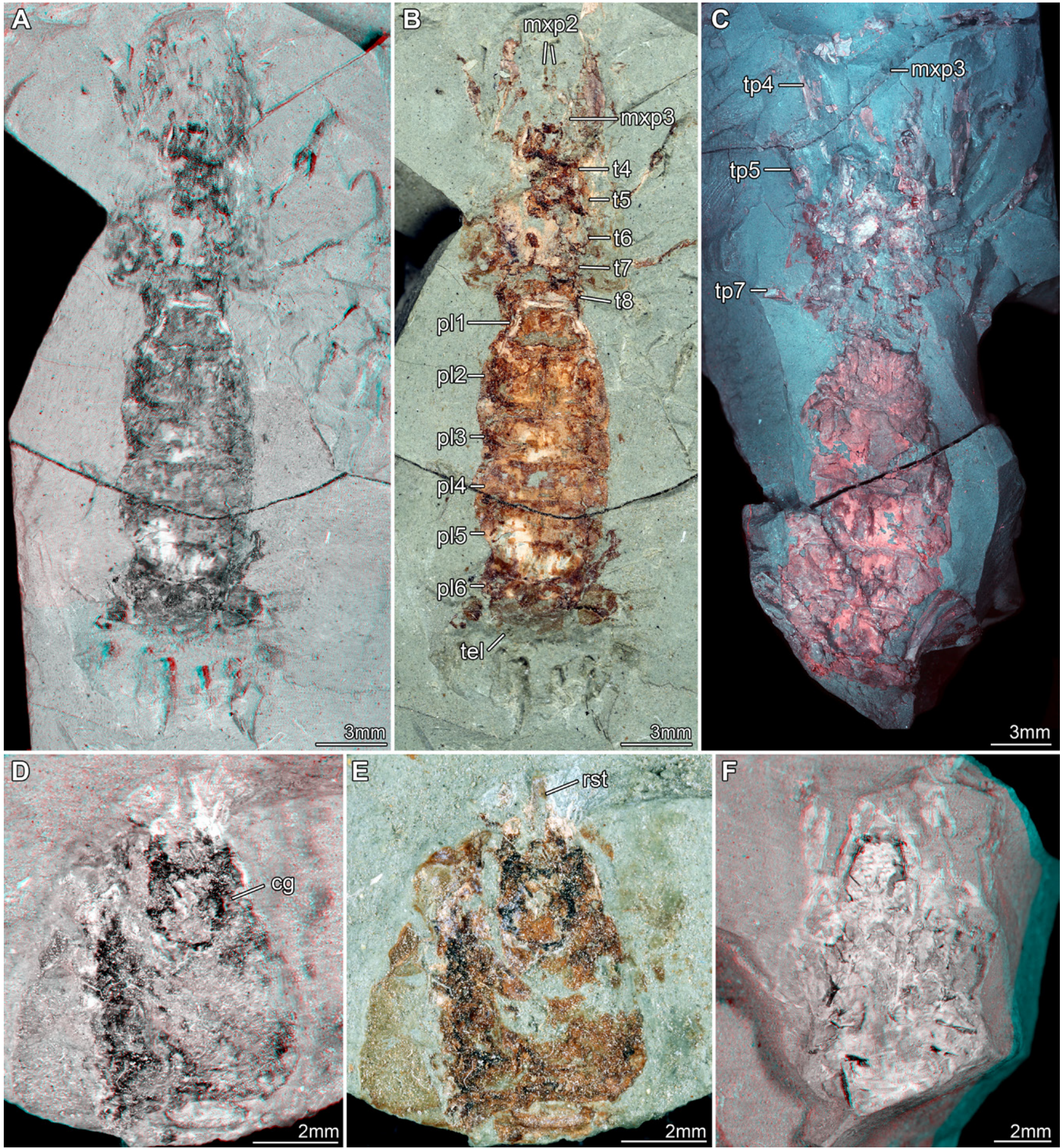

Figure 3. Overview (A-C) and cephalothorax (D-F) of Upogebia aronae sp. nov., dorsal view. A-B) SDSNH 104562, holotype. A) Red-cyan stereo image. B) Crossed-polarized light image; note the preservation of maxillipeds 2 and 3. C) SDSNH 104560; autofluorescence image with preserved thoracopods (same specimen as in Figure 4A-B). D-E) SDSNH 104566 as stereo image (D) and under polarized light (E). F) SDSNH 104568; stereo image; note ornamentation anterior to cervical groove. Other abbreviations than before: $\mathrm{mxp}=$ maxilliped; $\mathrm{t}=$ thoracomere; tel $=\mathrm{telson}$; $\mathrm{tp}=\mathrm{thoracopod}$.

the appendage to less than $90^{\circ}$, pointing to a notch in both articles (Figure 4G; $c f$. Figure 7B).

Appendage of post-ocular segment 10 (second "walking" leg, thoracopod 5) with four preserved articles. Smaller than preceding leg, about 0.85 times (Figure 4E, F). First preserved article (merus) almost 5 times as long as wide.
Second preserved article (carpus) about one third of the length of the merus; about 1.2 times as long as wide. Third preserved article (propodus) about 2 times the length of the carpus; about 2.8 times as long as wide. Fourth preserved article (dactylus) incomplete, elongate triangular. Joint formed by merus and carpus allows folding back the distal 

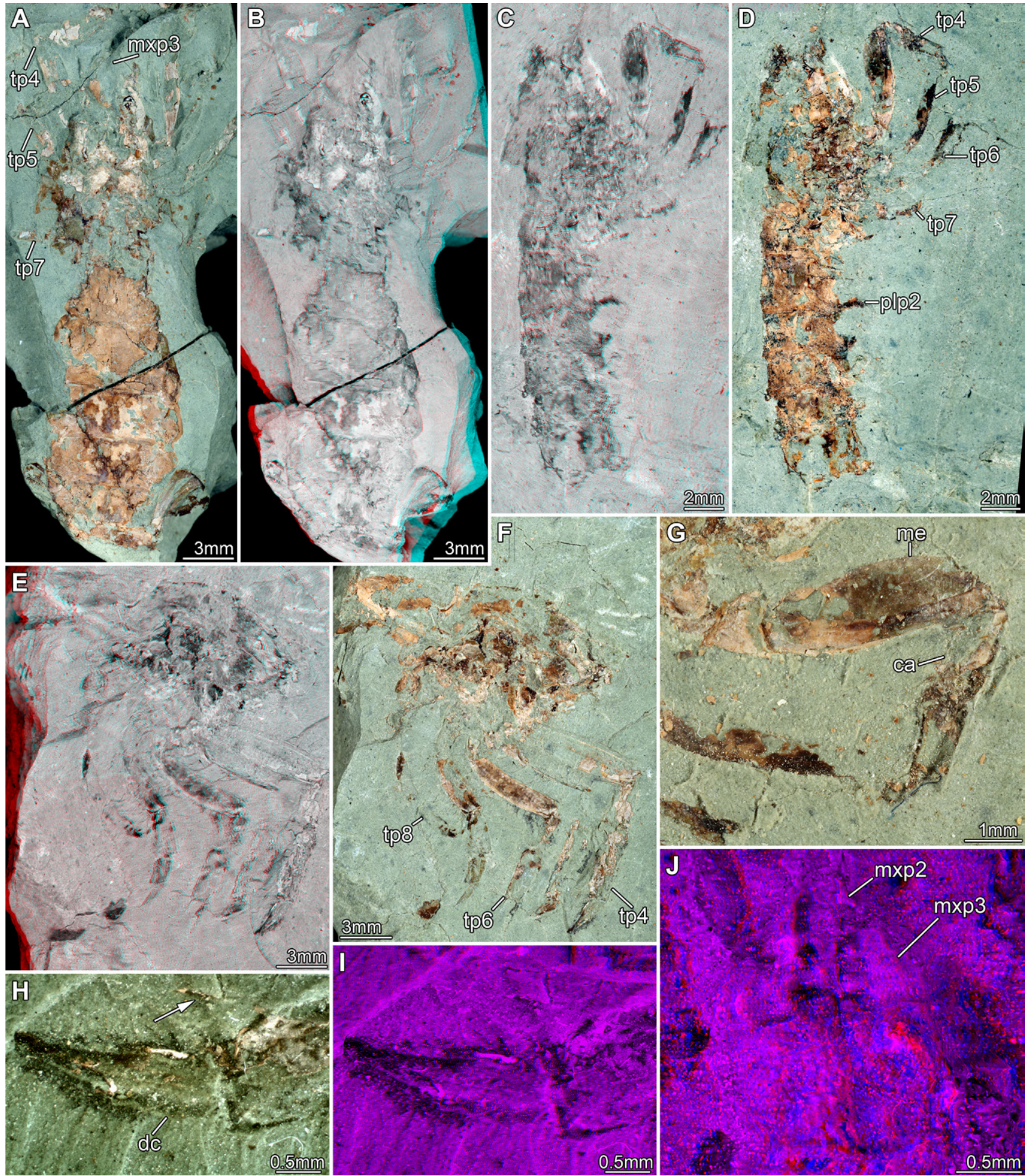

Figure 4. Appendages of Upogebia aronae sp. nov. A, D, F-H crossed-polarized light images; B, C, E, I, J red-cyan stereo images. A-B) SDSNH 104560; dorsal view with thoracopods preserved (same specimen as in Figure 3C). C-D) SDSNH 104559; lateral view with partly preserved thoracopods and pleopods (see also G). E-F) SDSNH 104565; lateral view. G) SDSNH 104559; close-up of thoracopod 4. H-I) SDSNH 104565; detail of dactylus of thoracopod 4; arrow marks fixed finger. J) SDSNH 104562, holotype; close-up of maxillipeds 2 and 3. Other abbreviations than before: ca $=$ carpus; dc $=$ dactylus; me $=$ merus; plp $=$ pleopod. 
part of the appendage to about $90^{\circ}$, pointing to a notch in both articles ( $c f$. extant comparative species).

Appendage of post-ocular segment 11 (third "walking" leg, thoracopod 6) with four preserved articles. Smaller than preceding leg, about 0.9 times (Figure 4E, F). First preserved article (ischium) incomplete. Second preserved article (merus) about 4 times as long as wide. Third preserved article (carpus) incomplete, about half the length of the merus. Fourth preserved article (propodus) slightly longer than the carpus; about 2.2 times as long as wide. Joint formed by merus and carpus allows folding back the distal part of the appendage to about $90^{\circ}$, pointing to a notch in both articles ( $c f$. extant comparative species).

Appendage of post-ocular segment 12 (fourth "walking" leg, thoracopod 7) with four preserved articles. Smaller than preceding leg, about 0.7 times (Figure 4E, F). First preserved article (merus) incomplete. Second preserved article (carpus) about 2 times as long as wide. Third preserved article (propodus) about 0.65 times the length of the carpus; about 1.7 times as long as wide. Fourth preserved article (dactylus) incomplete. Joint formed by merus and carpus not preserved in detail.

Appendage of post-ocular segment 13 (fifth "walking" leg, thoracopod 8) incomplete (Figure 4E, F). Appendages of post-ocular segments 14-18 (pleopods 1-5) incompletely preserved; apparently with a basipod and two distal rami (Figure 4C, D).

Appendage of post-ocular segment 19 (uropod) with basipod carrying the two distal rami, endopod and exopod (Figure 5A-D). Basipod relatively small, mainly concealed, no details accessible. Endopod rounded subtriangular in shape (Figure 5A, B, E, F, H, I). Anterior edge bulging. Additionally with one pronounced keel running from proximal to distal, parallel to anterior bulging edge (Figure 5E, F). Outer edge equipped with setae (indicated by preserved insertions). Exopod rounded triangular in shape, undivided (no diaresis) (Figure 5A-F). Anterior edge bulging. Additionally with two pronounced keels running from proximal to distal, parallel to anterior bulging edge (Figure 5E, F). Outer edge equipped with setae (indicated by preserved insertions) (Figure $5 \mathrm{G}$ ).

Telson almost square-shaped (Figure 5E, F, H, I). Midline of telson marked by median suture (Figure 5E, F). Posterior rim slightly convex, with a small notch at the midline (Figure 5E, F, H, I). Pleomere six with preserved muscles with identifiable muscle fiber bundles (diameter about $80 \mu \mathrm{m}$ ) and individual muscle fibers (diameter about $10 \mu \mathrm{m})$ (Figures 5I, 6).

\section{Discussion and conclusions}

\subsection{Affinities}

The preservation of the fossils described here is exceptional and far more complete than usually seen in fossil upogebiids. The following list of characters led us to determine the specimens as upogebiids ( $c f$. Dworschak et al., 2012 and references therein):

1) A well-developed U-shaped cervical groove is present.

2) The region anterior to this groove is coarsely ornamented.

3) The tail fan includes uropods with more or less triangular rami.

4) The anterior edges of both rami are bulged.

5) The uropodal exopod has two keels running parallel to the bulging anterior edge.

6) The uropodal exopod has no diaresis.

7) The uropodal endopod has one keel running parallel to the bulging anterior edge.

8) The telson is subrectangular, the posterior edge shorter than the anterior one.

9) A distinct suture marks the midline of the telson.

10) The posterior edge of the telson is convex with a weak median notch.

This combination of characters is found, for example, in the extant upogebiid depicted in Figure 7. The new material is mainly identified as representative of Upogebia as there are no detectable diagnostic characters that would draw it into any other genus. For example, an affinity to Austinogebia Ngoc-Ho, 2001 can be excluded for the present material as there is no prominent knob on the proximal shoulder of the latero-external border of the uropodal endopod ( $c f$. NgocHo, 2001). Unfortunately, many diagnostic characters of upogebiid genera concern features of the cephalothoracic shield such as carinae or ridges, but their presence or absence is difficult to evaluate in the new material, as those areas are compressed. Still, we did not erect a new genus due to the difficulty of formulating a valid diagnosis, and we support the view of Poore (2008) that Upogebiidae needs "a rigorous phylogenetic analysis and a stop to erection of new genera on the basis of possession of single character states or no explicit characters at all" (Poore, 2008, p. 423).

We see the erection of the new species Upogebia aronae in addition to the three coeval species from the USA, $U$. midwayensis Rathbun, 1935, U. gamma (Rathbun, 1935), and U. eocenica Rathbun, 1926, as justified for the following reasons:

1) U. eocenica has a broad, ornamented rostrum (Rathbun, 1926) in contrast to the slender, unornamented rostrum of $U$. aronae (this area is not preserved in $U$. midwayensis and U. gamma). A slender and unornamented rostrum is uncommon for upogebiids (Dworschak et al., 2012), but obviously diagnostic for $U$. aronae. Furthermore, $U$. eocenica bears three costae (corresponding to keels) on the endopod and two on the exopod, while $U$. aronae has one keel on the endopod and two keels on the exopod, in addition to an anterior bulging edge on both rami. Finally, the telson of $U$. eocenica is coarsely punctate with a deeply impressed median line, while both characters are missing in $U$. aronae (Rathbun, 1926). 

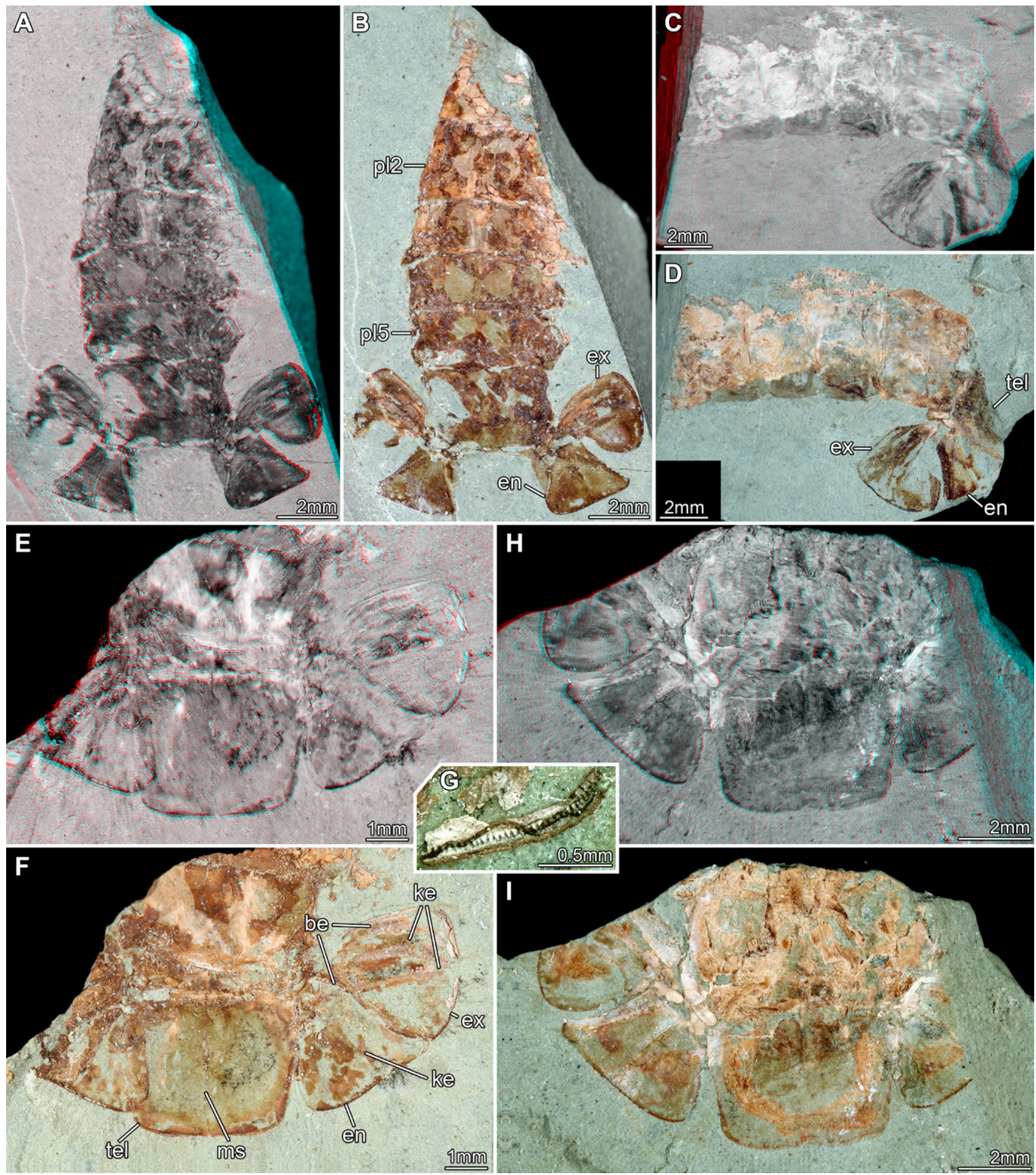

Figure 5. Tail fan of Upogebia aronae sp. nov. A, C, E, H red-cyan stereo images; B, D, F, G, I crossed-polarized light images. A-B) SDSNH 104564; pleon in dorsal aspect; uropods preserved with exo- and endopod, telson missing. C-D) SDSNH 104577; posterior part of pleon in lateral view. E-F) SDSNH 104580; tail fan with keels and median suture on telson. G) Close-up of outer edge of uropodal exopod of SDSNH 104580; note the insertions of setae. H-I) SDSNH 104581; pleomere 6 with muscle preservation (see Figure 6). Other abbreviations than before: be = bulged edges; en = endopod; ex $=$ exopod; $\mathrm{ke}=$ keel; $\mathrm{ms}=$ median suture; tel $=$ telson. 

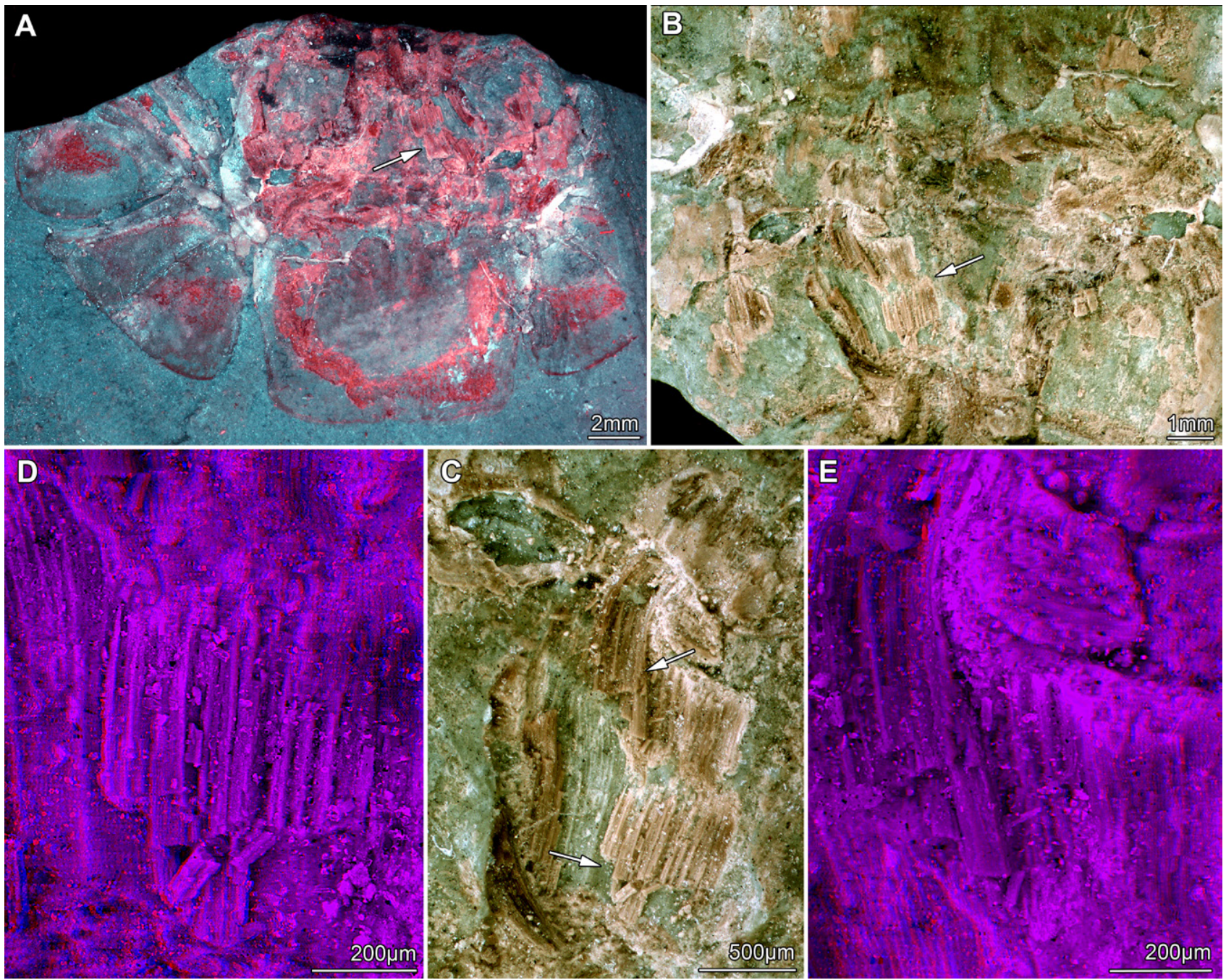

Figure 6. Muscle preservation in Upogebia aronae sp. nov., specimen SDSNH 104581. A) Autofluorescence image; arrow points to magnified area in B and C. B) Crossed-polarized light image, magnified and rotated $180^{\circ}$; arrow points to magnified area in C. C) Muscles with fiber bundles; arrows indicate close-ups in D and E. D-E) Red-cyan stereo images. D) Muscle fibers from area marked by lower arrow in C. E) Muscle fibers from area marked by upper arrow in $\mathrm{C}$.

2) While $U$. aronae has been discovered in southern California and thus occurred in the Pacific during the Eocene, both $U$. midwayensis and U. gamma were found in Alabama, and therefore lived in the Atlantic at the same time. Although there was still a connection between these two oceans during that time in what is today southern Mexico, this connection is so far south from the finding localities of the species that conspecifity of $U$. aronae with one of the two other species is regarded unlikely.

3 ) The fragmentary preservation of U. midwayensis and $U$. gamma hampers the morphological comparison with the new material. Furthermore, Fraaije et al. (2006) have argued that $U$. midwayensis and U. gamma may be the same species; however, better preserved specimens would be necessary to clarify this issue.

Given the current standard for upogebiid taxonomy (as well as for many other decapod groups), many morphological details have to be more clearly figured. For example, based on many descriptions, it remains difficult to judge whether the rami of the tail fan possess keels at all or whether they bear one or two keels. Especially when comparing extant forms with fossils, it will be necessary to include more photographic documentation of extant specimens; line drawings are often difficult to compare with incompletely preserved fossils. In addition, for relief structures such as keels modern documentation techniques in 3D should be applied as a standard procedure.

\subsection{Preservation}

As already stated, the preservation of the specimens described here must be considered as exceptional for a fossil upogebiid as most others are only represented fragmentarily (cf. Dworschak et al., 2012 and references therein). Probably the specimens of Upogebia aronae are among the best preserved upogebiids found to date (see also De Angeli and 


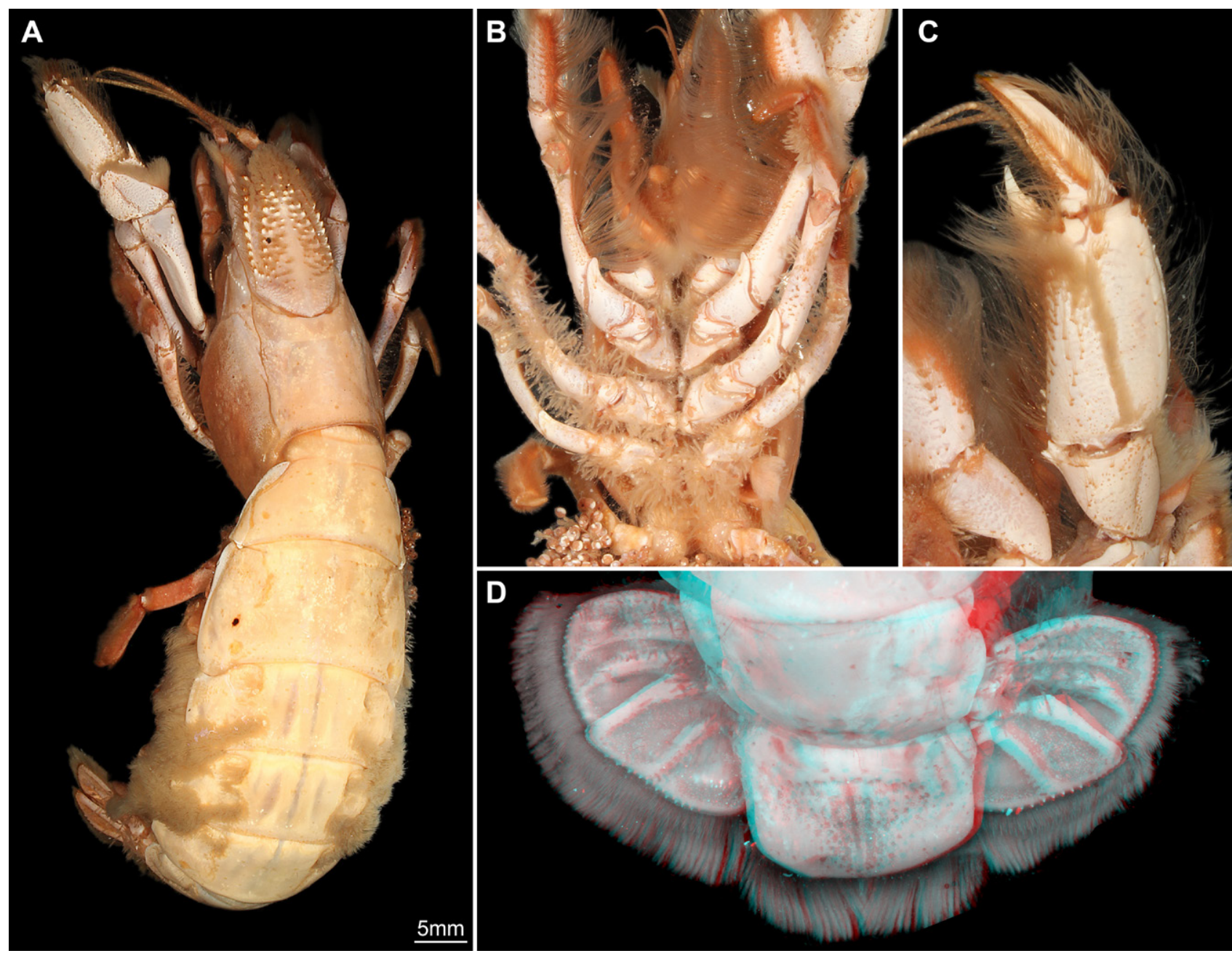

Figure 7. Extant representative of Upogebia pugettensis (Dana, 1852), immersed in alcohol; YPM IZ 058041. A-C) Crossed-polarized light images. A) Overview in latero-dorsal aspect. B) Ventral view on thoracopods. C) Detail of distal part of thoracopod 4. D) Red-cyan stereo image of tail fan; note the similarity to tail fan of Upogebia aronae sp. nov. (compare with Figure 5E-I).

Messina, 1992; Müller, 1993; Garassino et al., 2009). The exceptional details of the tail fan have only partly been found in the literature on other fossil upogebiids (e.g. Garassino et al., 2009). Also the preservation of maxillipeds two and three is exceptional. Especially the second maxilliped is rarely found in fossil reptantians in general as it is hardly visible in dorsal preservation, but concealed by the third maxilliped in ventral or lateral preservation.

As the specimens of Upogebia aronae are threedimensional to a certain extent, many of the interesting morphological aspects, such as the maxillipeds, are preserved; the slightly flattened nature of the specimens, on the other hand, left most parts in an articulated organization and usually in their natural position without the need of carving them completely out of the matrix. Based on the fluorescence capacities of the specimens they are most likely composed of calcium phosphate (e.g. Haug et al., 2009; Haug et al., 2011). Although calcium phosphatic fossils are especially famous in limestone matrix, in the present case they occur in a claystone with highly detailed preservation of structures. While fine hairs as those found in fossils from lithographic limestones (e.g. Haug et al., 2010) are not preserved, their presence is partly indicated by their preserved insertions (Figure 5G). Unfortunately, such details cannot be clearly shown for the walking appendages of $U$. aronae due to lack of preservation. The strong setation on these appendages is characteristic for Upogebia and its close relatives (e.g. Williams, 1986; Sakai, 2006).

The most striking aspect of the exceptional preservation in the specimens of Upogebia aronae is the preservation of muscles in pleomere six (Figure 6). Based on the position of the muscles, these could be part of the muscular system that moves the uropod, but it can also not be excluded that these muscles operated the telson (for comparison with muscles in extant $U$. pugettensis, see Paul et al., 1985, their figure 1B1, B2). Several muscle strands are preserved; preservation of muscles in calcium phosphatic arthropod fossils is not unusual, but still rare (for structural details see Wilby and Briggs, 1997). An impressive example of muscle preservation is known from a phosphatic 
microfossil, a pentastomid from the Ordovician of Sweden in 'Orsten'-type preservation (Andres, 1989, his Table 2 and Figures 4-8; see also Maas et al., 2006, their Figure $4 \mathrm{G})$. But also macrofossils such as horseshoe crabs (Xiphosura) from the Jurassic lithographic limestones of southern Germany are known to preserve exquisite details of muscles (Briggs and Wilby, 1996; Briggs et al., 2005). In addition, examples of fossil muscle preservation from different decapods are known (e.g. Briggs and Kear, 1994; Feldmann and Schweitzer, 2010). In the present case, not only the muscles themselves can be identified, it appears that individual muscle fiber bundles (diameter of about 80 $\mu \mathrm{m}$ ) and individual muscle fibers (slightly more than $10 \mu \mathrm{m}$ in diameter) can be identified (Figure 6C-E).

The exceptional preservation as well as the relative abundance of the specimens, compared to other fossil upogebiids, was most likely facilitated by a rapid in situ burial preservation of the fossils. Yet, although the specimens must be interpreted as being preserved in situ, no corresponding burrows that could have been produced by the specimens described here have been reported from their locality.

\subsection{Paleoecology}

The presence of fossil upogebiids in relatively high abundances and occurring within a small $1.5 \mathrm{~m}$ section is of interest for a comparison with extant ecosystems. Upogebiids occur in extremely high densities in modern tidal flats, for example, up to 200 individuals per square meter (Dworschak, 1987). The relatively large number of specimens of Upogebia aronae found together corresponds with the assumption that the original fossil community had abundances that were comparable to those of modern faunas. The fossils described here were collected from a locality that was considered to represent an estuarine to nearshore marine and non-marine sandstone, siltstone, mudstone, and cobble breccia beds of member "B" of the Eocene-age Santiago Formation (Tan and Kennedy, 1996; Deméré and Murphy, 2006). This general stratigraphic trend from non-marine at the base to estuarine/nearshore marine at the top suggests that deposition occurred during a marine transgressive period in middle Eocene time (Deméré and Murphy, 2006).

When screening the literature, one gets the impression that other fossil occurrences of upogebiids are often limited to few specimens or even a single specimen (e.g. Fraaije et al., 2006 and references therein). However, this is probably only true for better preserved specimens ( $c f$. Bishop and Williams, 2005), while fragmentary specimens are often not collected or not mentioned in the literature (as counterexamples see Rathbun, 1926, 1935; Bishop and Williams, 2005; Garassino et al., 2012). The burrowing life habit of upogebiids should make fossilization more likely; yet in situ remains of specimens within their burrows seem to be relatively rare (e.g. Ando and Karasawa, 2010; and summary in Hyžný, 2011). Whether this observation hints to a different ecological niche in certain fossil upogebiids as opposed to extant ones, or it simply reflects a reporting bias, it needs to be checked (Hyžný, pers. com). Nonetheless, life habits similar to those of modern upogebiids can be confirmed for the specimens described here.

These specimens could thus represent a case in which we have access to a paleo-population of upogebiids, or at least to a significant part of it. There appears to be little size variance among the specimens indicating the absence of juvenile individuals so that we actually face coexisting adults. In extant upogebiid populations, adults and juveniles co-occur (e.g. Dworschak, 1983), so the lack of juveniles in our case might be taphonomically biased.

In conclusion, the new finding represents several rare occurrences: the preservation of a large number of fossil upogebiids and their exceptional preservation including well preserved muscles. This combination makes the current discovery exceptional.

\section{Acknowledgements}

We want to thank several people that made this study possible. Joachim T. Haug, University of Greifswald, helped with documenting the specimens and processing the images. Eric Lazo-Wasem and Lourdes Rojas, both at Yale Peabody Museum of Natural History, New Haven, provided access to the extant upogebiid specimen. Derek E.G. Briggs, Yale University and Peabody Museum, hosted and supported C.H. during her research visit at the Yale Peabody Museum. Steffen Harzsch currently hosts and supports C.H. at the University of Greifswald. C.H. was kindly funded by the German Academic Exchange Service (DAAD). We would also like to thank Scott Rugh, Kesler Randall, and Tom Deméré of the San Diego Natural History Museum for kindly loaning us the fossil specimens. Matús Hyžný, Comenius University Bratislava, made very helpful suggestions which significantly improved the content of this paper. We furthermore thank all people that spend their time in providing open source, open access or lowcost software, which was used during this study, such as OpenOffice, GIMP, CombineZM/ZP, Microsoft ICE, and Image Analyzer.

\section{References}

Ando, Y., Karasawa, H., 2010, Mud shrimp associated with burrows from the Oligocene Ashiya Group, northern Kyushu, Japan, with description of a new species of Upogebia (Decapoda: Gebiidea): Zootaxa, 2337, 63-68.

Andres, D., 1989, Phosphatisierte Fossilien aus dem unteren Ordoviz von Südschweden: Berliner geowissenschaftliche Abhandlungen (A), 106, 9-19.

Bengtson, S., 2000, Teasing fossils out of shales with cameras and computers: Palaeontologia Electronica, 3, art. 4, 14 p. 
Bishop, G.A., Williams, A.B., 2005, Taphonomy and preservation of burrowing thalassinidean shrimps: Proceedings of the Biological Society of Washington, 118, 218-236

Boas, J.E.V., 1880, Studier over Decapodernes Slaegtskabsforhold: Kongelige Danske videnskabernes Selskabs Skrifter, 6, 25-210.

Borradaile, L.A., 1903, On the classification of the Thalassinidea: Annals and Magazine of Natural History (ser. 7), 12, 534-551.

Briggs, D.E.G., Kear, A.J., 1994, Decay and mineralization of shrimps: Palaios, 9, 431-456.

Briggs, D.E.G., Moore, R.A., Shultz, J.W., Schweigert, G., 2005, Mineralization of soft-part anatomy and invading microbes in the horseshoe crab Mesolimulus from the Upper Jurassic Lagerstätte of Nusplingen, Germany: Proceedings of the Royal Society of London, B 272, 627-632.

Briggs, D.E.G., Wilby, P.R., 1996, The role of the calciuim carbonate - calcium phosphate switch in the mineralization of soft-bodied fossils: Journal of the Geological Society of London, 153, 665-668.

Burkenroad, M.D., 1963, The evolution of the Eucarida (Crustacea, Eumalacostraca), in relation to the fossil record: Tulane Studies in Geology, 2, 1-17.

Dana, J.D., 1852, Crustacea. Part II, in United States Exploring Expedition During the Years 1838, 1839, 1840, 1841, 1842 Under the Command of Charles Wilkes, U.S.N. 13(2): 689-1618 (1853), folio atlas pls. $1-96(1855)$

De Angeli, A., Messina, V., 1992, Upogebia perarolensis nuova specie di crostaceo del Terziario del Veneto (Italia): Lavori da Società Veneto di Scienze naturali, 17, 183-191.

de Saint Laurent, M., 1979, Vers une nouvelle classification des Crustacés Décapodes Reptantia: Tunisie, Bulletin Office National Pêche, 3, 15-31.

Deméré, T., Murphy, P.C., 2006, Paleontological Mitigation Report Bressi Ranch City of Carlsbad San Diego County, California: San Diego, California, San Diego Natural History Museum, Department of Paleoservices, $28 \mathrm{p}$.

Deméré, T.A., Walsh, S.L., 1993, Paleontological Resources, County of San Diego: Prepared for the San Diego Planning Commission, 1-68.

Dworschak, P.C., 1983, The biology of Upogebia pusilla (Petagna) (Decapoda, Thalassinidea). I. The burrows: Marine Ecology, 4, 19-43.

Dworschak, P.C., 1987, Feeding behaviour of Upogebia pusilla and Callianassa tyrrhena (Crustacea, Decapoda, Thalassinidae): Investigación Pesqueras, 51 (Suplemento 1), 421-429.

Dworschak, P.C., Felder, D.L., Tudge, C.C., 2012, Chapter 69. Infraorders Axiidea de Saint Laurent, 1979 and Gebiidea de Saint Laurent, 1979 (formerly known collectively as Thalassinidea), in Schram, F.R., von Vaupel Klein, J.C. (eds.), Treatise on Zoology - Anatomy, Taxonomy, Biology, 9, part B: Leiden, The Netherlands, Brill, 109-219.

Feldmann, R.M., Schweitzer, C.E. 2010. The oldest shrimp (Devonian: Famennian) and remarkable preservation of soft tissue: Journal of Crustacean Biology, 30, 629-635.

Fraaije, R.H.B., van Bakel, B.W.M., Jagt, J.W.M., Coole, Y., 2006, Two new Paleogene species of mud shrimp (Crustacea, Decapoda, Upogebiidae) from Europe and North America: Bulletin of the Mizunami Fossil Museum, 33, 77-85.

Garassino, A., Artal, P., Pasini, G., 2009, Upogebia miocenica n. sp. (Crustacea, Thalassinidea, Upogebiidae) from the Miocene of Catalonia (Spain): Atti della Società italiana di Scienze naturali e del Museo civico di Storia naturale di Milano, 150, 61-68.

Garassino, A., Pasini, G., De Angeli, A., Charbonnier, S., Famiani, F., Baldanza, A., Bizzarri, R., 2012., The decapod community from the Early Pliocene (Zanclean) of "La Serra" quarry (San Miniato, Pisa, Toscana, central Italy): sedimentology, systematics, and palaeoenvironmental implications: Annales de Paléontologie, 98, 1-61.

Glaessner, M.F., 1969, Decapoda, in Moore, R.C. (ed.), Treatise on invertebrate paleontology, part R. Arthropoda 4, vol. 2: Lawrence, Kansas, University of Kansas Printing Service, 399-533.

Haug, C., Haug, J.T., Waloszek, D., Maas, A., Frattigiani, R., Liebau, S.,
2009, New methods to document fossils from lithographic limestones of southern Germany and Lebanon: Palaeontologia Electronica, 12 , art. $6 \mathrm{~T}$.

Haug, J.T., Haug, C., Ehrlich, M., 2008, First fossil stomatopod larva (Arthropoda: Crustacea) and a new way of documenting Solnhofen fossils (Upper Jurassic, Southern Germany): Palaeodiversity, 1, 103-109.

Haug, J.T., Haug, C., Maas, A., Kutschera, V., Waloszek, D., 2010, Evolution of mantis shrimps (Stomatopoda, Malacostraca) in the light of new Mesozoic fossils: BMC Evolutionary Biology, 10, art. $290,17 \mathrm{p}$.

Haug, J.T., Haug, C., 2011, Fossilien unter langwelligem Licht: GrünOrange-Fluoreszenz an makroskopischen Objekten: Archaeopteryx, $29,20-23$.

Haug, J.T., Haug, C., Kutschera, V., Mayer, G., Maas, A., Liebau, S., Castellani, C., Wolfram, U., Clarkson, E.N.K., Waloszek, D., 2011, Autofluorescence imaging, an excellent tool for comparative morphology: Journal of Microscopy, 244, 259-272.

Haug, J.T., Briggs, D.E.G., Haug, C., 2012, Morphology and function in the Cambrian Burgess Shale megacheiran arthropod Leanchoilia superlata and the application of a descriptive matrix: BMC Evolutionary Biology, 12, art. 162., 20 p.

Hyžný, M., 2011, In situ mud shrimps (Decapoda: Axiidea: Callianassidae) preserved within their burrows from the middle Miocene of the Central Paratethys: Bulletin of the Mizunami Fossil Museum, 37, 37-46.

Kerp, H., Bomfleur, B., 2011, Photography of plant fossils-new techniques, old tricks: Review of Palaeobotany and Palynology, $166,117-151$

Latreille, P.A., 1802, Histoire naturelle, générale et particulière, des Crustacés et des Insectes: Paris, F. Dufart, Tome 3, xii +467 p.

Leach, W.E., 1813-1814, Crustaceology, in Brewster, D., The Edinburgh Encyclopædia: Edinburgh, A. Balfour, 383-437.

Maas, A., Braun, A., Dong Xiping, Donoghue, P.C.J., Müller, K.J., Olempska, E., Repetski, J.E., Siveter, Da.J., Stein, M., Waloszek, D., 2006, The 'Orsten' - more than a Cambrian Konservat-Lagerstätte yielding exceptional preservation: Palaeoworld, 15, 266-282.

Montagu, G., 1808, Description of several marine animals found on the south coast of Devonshire: Transactions of the Linnean Society of London, 9, 81-114.

Müller, P., 1993, Neogene Decapod Crustaceans from Catalonia: Scripta Musei Geologici Seminari Barcinonensis, 225, 1-39.

Ngoc-Ho, N., 2001, Austinogebia, a new genus in the Upogebiidae and rediagnosis of its close relative, Gebiacantha Ngoc-Ho, 1989 (Crustacea: Decapoda: Thalassinidea): Hydrobiologia, 449, 47-58.

Paul, D.H., Then, A.M., Magnuson, D.S., 1985, Evolution of the telson neuromusculature in decapod Crustacea: Biological Bulletin, 168, 106-124.

Poore, G.C.B., 2008, Book review: Sakai, K. 2006. Upogebiidae of the world (Decapoda, Thalassinidea). Crustaceana Monographs 6, i-ix, 185 pp., 23 textfigs. Koninklijke Brill, NV, Leiden, The Netherlands: Journal of Crustacean Biology, 28, 422-423.

Rathbun, M.J., 1926, The fossil stalked-eyed Crustacea of the Pacific slope of North America: Bulletin of the United States National Museum, 138, 1-156.

Rathbun, M.J., 1935, Fossil Crustacea of the Atlantic and Gulf Coastal Plain: Geological Society of America Special Paper, 2, 1-160.

Sakai, K., 2006, Upogebiidae of the world (Decapoda, Thaassinidea): Crustaceana Monographs, 6, 1-185.

Schaarschmidt, F., 1973, Pflanzenfossilien in ungewöhnlichem Licht: Natur und Museum, 103, 247-253.

Schram, F.R., 1986, Crustacea: New York, Oxford University Press, 606 p. Schweitzer, C.E., Feldmann, R.M., 2002, New Eocene decapods (Thalassinidea and Brachyura) from southern California: Journal of Crustacean Biology, 22, 938-967.

Tan, S.S., Kennedy, M.P., 1996, Geologic maps of the northwestern part of San Diego, California, 1:24000: San Diego, California, California Division of Mines and Geology, Open-File Report 96-02, 2 sheets. 
Walsh, S.L., 1996, Middle Eocene mammal faunas of San Diego County, California, in Prather, D.R., Emry, R.J. (eds.), The Terrestrial Eocene Oligocene Transition in North America: Cambridge, England, Cambridge University Press, 75-119.

Wilby, P.R., Briggs, D.E.G., 1997, Taxonomic trends in the resolution of detail preserved in fossil phosphatized soft tissues: Geobios, Mémoire spécial, 20, 493-502.

Williams, A.B., 1986, Mud shrimps, Upogebia, from the eastern Pacific (Thalassinoidea: Upogebiidae): San Diego Society of Natural History Memoir, 14, 1-60.

Wilson, K.L., 1972, Eocene and related geology of a portion of the San Luis Rey and Encinitas quadrangles, San Diego County, California: Riverside, California, University of California Riverside, M.Sc. thesis, $135 \mathrm{p}$.
Woodring, W.P., Popenoe, W.P., 1945, Paleocene and Eocene stratigraphy of northwestern Santa Ana Mountians, Orange County, California: U.S. Geological Survey Oil and Gas Investigations, Preliminary Chart 12.

Manuscript received: September 2, 2012.

Corrected manuscript received: October 21, 2012.

Manuscript accepted: December 20, 2012. 